\title{
Taxes and Women in the Labour Force in a Southern European Country: The Case of Portugal
}

\section{Ana Cristina Lino Marques - Pedro Telhado Pereira}

\begin{abstract}
On looking at the female labour supply in Europe, it is immediately noticed that there is a large variation among countries. One possible explanation for this fact is that different countries have different tax policies, leading to variations in incentive and costs. This has been investigated in papers such as that of Gustafsson (1992a,b) for countries such as Germany and Sweden. The same exercise has been performed by the present authors for a low-income, southern European country, Portugal, which has one of the highest rates of female participation (out of line with neighbouring countries). Female labour supply does not seem to be very sensitive to fiscal policies, as those policies have only a small influence on the take-home wage. This result appears to be independent of the fact that the female labour supply shows a higher elasticity to wages than that which has been reported for other countries. The present authors also show that Portuguese women contribute a much larger proportion of family earnings than do their counterparts in Sweden and Germany, and that the Portuguese fiscal system is rather neutral. Further studies with data from other countries are needed in order to shed more light on the issue of tax harmonization.
\end{abstract}

\section{Introduction}

Portugal has a rather peculiar female labour market supply. In 1996, the country showed a high female activity rate ${ }^{1}$ (49.3 percent), much higher than that which is found in the other southern European countries (namely, 36.2 percent for Spain, 34.6

Anna Cristina Lino Marques, ISCAL, Av. Miguel Bombarda, 20, P-1050 Lisbon, Portugal.

Pedro Telhado Pereira, Faculdade de Economia, Universidade Nova de Lisboa, Trav. Estevão Pinto, P-1070 Lisbon, Portugal. 
percent for Italy and 36.6 percent for Greece). Still, it retains some of these other countries' characteristics, such as a low incidence of part-time work (13 percent in 1996), a high concentration in the primary sector (13.5 percent in 1996) and low concentration in the tertiary sector (64.5 percent in 1996). The fact that Portugal differs from the countries with which it is generally grouped (southern Mediterranean), invites a search for reasons.

Among the factors contributing to Portugal's elevated participation of women in the labour force, some researchers (for instance, Meulders et al., 1991) have pointed to the colonial war, to the high emigration of prime age males in the 1960s and to the 1974 revolution, and the political, cultural, social and economic changes which it brought on.

Some studies for the central-northern European countries have shown that differences in female participation can be explained by different tax systems (see, for instance, Aaberge et al., 1993; Agell, Apel, 1991; Bourguignon, Magnac, 1990; Colombino, Del Boca, 1990; Dex, Walters, 1992; Gustafsson, 1988, 1992a,b), an issue of great interest to the discussion of fiscal harmonization in the European Union. 'Is the Portuguese tax system a strong contributing factor to the pattern observed in female participation in the labour market?' This is the question addressed in this paper.

Data were used on earnings and individual characteristics for 2322 married couples in 1990. The main features of Portuguese income tax and of the fiscal systems implemented (joint taxation with a splitting factor of 2.0, separate taxation and a flat rate) were programmed, in order to calculate the after-tax income to be used in the simulations.

The results show that married women in Portugal have a higher elasticity of labour supply in terms of take-home pay than in all the other studies cited above. In terms of the simulations for different taxation regimes, the changes in labour supply are small when compared with those for other countries. However, it should be recalled that Portugal has the lowest per capita income of the countries considered, and the fiscal systems employed have little effect on after-tax earnings. It would therefore seem that the tax system is not a major factor in explaining the Portuguese figures. It is also shown that the contribution of the wife's earnings to the household income is the same, before and after taxes; in this sense the Portuguese fiscal system can be considered as being 'neutral'.

The paper is organized in the following way. Firstly, in Section 2, the tax system in Portugal is introduced. In Section 3 
the data and the variables are described. Next, the econometric model is specified and the empirical results are analysed. Then, in Section 5, the results of tax simulations are given and these are compared with those obtained in the literature, in particular with those of Gustafsson (1992a,b) for Germany and Sweden. Finally, in the concluding section, the findings are summarized.

\section{The personal income tax system in Portugal}

In 1990, the tax unit in Portugal is the family, a case of a joint taxation system. It could be said that the Portuguese system is halfway between that of Germany (a splitting taxation system) and that of Sweden (separate taxation) - the countries studied by Gustafsson (1992a,b). In fact, Portugal has a 'mixed' splitting system - the splitting coefficient is 2.0 if the couple is two-earner and is 1.85 if the couple is one-earner (in 1990).

The Portuguese tax system is also a progressive one and tax is withheld from payroll earnings at source. For further details see the Appendix.

\section{Data and variables}

Data used for the estimation were obtained from the 'Inquéritos do $3^{\circ}$ trimestre aos dados do emprego de 1990' of the Instituto Nacional de Estatística, where information is gathered regarding gender, age, relationship with the head of the household, labour participation, education, net monthly earnings and hours of work per week for each individual.

The sample used was built from 6940 families, where the selection criterion was 'married women with employed husbands present'. From this sample, the present authors selected only those couples where the wife was between 17 and 59 years of age, for whom information was available about the relevant variables used in this study (namely, hours of work per week of the husband and of the wife, if she works in the labour market, and net monthly wages). Some observations were deleted because the number of hours of work per week was inadequate. The total number of observations of married women in the final sample was 2322.

Some problems appear with the net wages, as the data were collected in 13 brackets which correspond to 13 levels. We took for 
Table 1. Descriptive statistics $(n=2322)$

\begin{tabular}{|c|c|c|c|c|}
\hline Variables & Mean & Standard deviation & Minimum & Maximum \\
\hline $\begin{array}{l}\text { Proportion of women } \\
\text { in the labour market } \\
(\mathrm{LFP})^{\mathrm{a}}\end{array}$ & 0.55168 & 0.49743 & 0 & 1 \\
\hline $\begin{array}{l}\text { Proportion of women } \\
\text { working full time } \geqslant 30 \\
\text { hours per week) } \\
(\text { FTLFP) }\end{array}$ & 0.48751 & 0.49995 & 0 & 1 \\
\hline $\begin{array}{l}\text { Proportion of women } \\
\text { working full time } \geqslant 35 \\
\text { hours per week) }\end{array}$ & 0.47027 & 0.49922 & 0 & 1 \\
\hline Number of children & 1.6223 & 1.0853 & 0 & 11 \\
\hline $\begin{array}{l}\text { Number of children } \\
\text { under } 3 \text { years old }\end{array}$ & 0.20284 & 0.44201 & 0 & 2 \\
\hline $\begin{array}{l}\text { Number of children, } \\
3-6 \text { years old }\end{array}$ & 0.19423 & 0.42610 & 0 & 3 \\
\hline $\begin{array}{l}\text { Number of children } \\
\text { over } 6 \text { years old }\end{array}$ & 1.2188 & 1.0938 & 0 & 8 \\
\hline Wife's age/10 & 3.8252 & 0.94037 & 1.700 & 5.900 \\
\hline Wife's age squared/100 & 15.516 & 7.4224 & 2.890 & 34.810 \\
\hline $\begin{array}{l}\text { Wife's education } \\
\text { (years) }\end{array}$ & 7.1589 & 3.7338 & 0 & 18 \\
\hline $\begin{array}{l}\text { Wife's experience } \\
\text { (years) }\end{array}$ & 12.479 & 13.4405 & 0 & 52 \\
\hline $\begin{array}{l}\text { Wife's experience } \\
\text { squared (years) }\end{array}$ & 336.29199 & 479.37287 & 0 & 2704 \\
\hline Wife's weekly hours & 21.07321 & 20.02497 & 0 & 72 \\
\hline $\begin{array}{l}\text { Husband's weekly } \\
\text { hours }\end{array}$ & 42.56934 & 7.69684 & 5 & 90 \\
\hline $\begin{array}{l}\text { Wife's pre-tax monthly } \\
\text { earnings (1000 PTE) }\end{array}$ & 38.75592 & 50.52733 & 0 & 192.5210 \\
\hline $\begin{array}{l}\text { Husband's pre-tax } \\
\text { monthly earnings ( } 1000 \\
\text { PTE) }\end{array}$ & 85.98715 & 45.62269 & 16.3480 & 192.9220 \\
\hline $\begin{array}{l}\text { Family after-tax } \\
\text { earnings at } H_{F}=0 \\
(10,000 \text { PTE })\end{array}$ & 110.13889 & 51.43235 & 22.8872 & 226.0541 \\
\hline
\end{tabular}

Notes: ${ }^{\mathrm{a}} \mathrm{LFP}=$ labour force participation.

${ }^{\mathrm{b}} \mathrm{FTLFP}=$ full-time labour force participation. 
net monthly wage the average point of each bracket was taken, and for the first (last) bracket it was assumed that the amplitude of this interval was identical to the next (previous) one.

The gross wage was fundamental to this study. To calculate it, it was assumed that the net wage stated in the survey:

(1) is net of taxes (for further details see the Appendix); ${ }^{2}$

(2) is net of Social Security contributions (at a rate of 11 percent of gross earnings);

(3) includes the meal allowance $-350 \mathrm{PTE}^{3} \times 21$ days (which is equal to the Public Administration provision) in the absence of other information;

(4) includes family allowances, which is equal to 1550 PTE for each child or 2350 PTE for the third and subsequent child if the aggregate household income is less than $1.5 \times$ minimum annual income provided for all the workers (which in 1990 was $14 \times 35,000$ PTE) (Fernandes, Santos, 1990). Note that Portuguese workers were paid 14 times $^{4}$ per year and received a meal allowance for each day of work.

The descriptive statistics of the relevant variables used are shown in Table 1.

The variable 'Wife's potential experience' is calculated using:

AGE - EDUC - 6,

which is the convention found in the labour supply literature, when primary school starts at age 6, as in the Portuguese case.

The sample distribution of weekly hours of work is presented in Table 2.

The distribution of hours for women indicates that this sample accurately reflects the Portuguese case in that there is a low acceptance of part-time work (8.1 percent). However, the married female labour force participation rate in the sample (55.2 percent) is lower than the overall Portuguese rate (61.3 percent in 1990).

Table 2. Frequency distribution of women's weekly hours worked

\begin{tabular}{lrr}
\hline Hours/week & Count & Percent \\
\hline 0 & 1041 & 44.83 \\
$1-19$ & 52 & 2.24 \\
$20-34$ & 137 & 5.90 \\
$\geqslant 35$ & 1092 & 47.03 \\
\hline
\end{tabular}


Table 3. Average weekly hours worked

\begin{tabular}{lcc}
\hline & $\boldsymbol{H}_{\boldsymbol{F}}$ & $\boldsymbol{H}_{\boldsymbol{M}}$ \\
\hline All couples & 21.0732 & 42.5693 \\
Two-earner couples & 38.1983 & 42.0804 \\
\hline
\end{tabular}

The wife's average weekly hours of work were calculated for the entire sample and for two-earner couples (see Table 3). Estimated average weekly working hours for Portuguese women in twoearner couples are substantially higher than those obtained by Gustafsson (1992a,b) for German and Swedish working women (30 hours).

\section{Empirical results}

To predict wives' pre-tax wages, the present authors used the information available on the wages of the wives who do work.

Table 4. Wife's wage regressions (Heckman's method)

Regressors

Dependent variable Log. of hourly pre-tax

Constant wage

Wife's education

$3.78191^{*}$

(16.677)

$0.170546^{*}$

Wife's experience

(14.643)

Wife's experience squared

0.0306029

(4.871)

$-0.000347404^{* *}$

$\hat{\lambda}^{\mathrm{a}}$

$(-2.524)$

$0.457674^{* *}$

(2.590)

Adjusted $R^{2}$

0.586659

F

455.1786

Number of observations

1281

Mean of dependent variable

5.9743

Notes: ${ }^{a} \hat{\lambda}=$ Mill's ratio, which has been estimated using Heckman's method (running a probit regression on the probability of having an observed wage).

* Significant at 1 percent level; ${ }^{* *}$ significant at 5 percent level. $t$-values are shown in parentheses. 
However, working wives are a self-selected group. To correct the sample selection bias on the wives' pre-tax wage regression, Heckman's method was used (Heckman, 1980), estimating the Mill's ratio on the probability of having an observed wage (Greene, 1990; Gustafsson, 1992a; Maddala, 1983).

Table 4 shows the gross earnings parameter estimates corrected for selectivity bias.

As can be observed, the coefficient associated with the inverse Mill's ratio $(\hat{\lambda})$ is positive and significant. This means that the working wives in the sample earned higher market wages than might be expected from their characteristics. Dex and Walters (1992) suggest career ambition as a possible explanation for this phenomenon.

Then, for the married women participation rate to be estimated, the likelihood function is maximized for the following logit:

$$
P=\log \frac{\operatorname{prob}(Y=1)}{1-\operatorname{prob}(Y=1)}=\beta_{0}+\beta_{1} W_{n}+\beta_{2} R+K \beta_{K}+A \beta_{A}+\mu,
$$

where $Y$ assumes the value 1 if the woman participates in the labour force, and the value 0 if she does not; $W_{n}$ is the wife's aftertax pay at 20 or 40 hours for women in the labour market, or the estimates from the Heckman method for those not in the labour market; $R$ is the family income other than wife's earnings; $K$ denotes a vector of variables associated with children's age and number; while $A$ is a vector of variables attached to the wife's age.

The estimated probability of labour force participation is then obtained as

$$
\operatorname{prob}\left(Y_{i}=1\right)=\frac{\exp \left(\hat{P}_{i}\right)}{1+\exp \left(\hat{P}_{i}\right)}
$$

A few words about $W_{n}$ are in order. To overcome the problems of non-linearity of the budget constraint due to progressive taxes, some specified points of the budget constraint were investigated (for more details see Brownstone et al., 1988; Gustafsson, 1992a). In so doing, the wife's after-tax pay becomes exogenous to the wife's labour supply decision.

The net wage at 20 and 40 hours was calculated, using the 20 hour net wage to explain the probability of working in the labour 
Table 5. Logit estimation of the labour force participation function for Portuguese married women

(1)

\begin{tabular}{|c|c|c|c|c|}
\hline \multirow[b]{3}{*}{ Regressors } & & & \multirow{3}{*}{ FTLFP $^{b}$} & \multirow{3}{*}{$\frac{\partial \boldsymbol{F T} \boldsymbol{T} \boldsymbol{F P}}{\partial \boldsymbol{X}}$} \\
\hline & \multirow{2}{*}{$\mathbf{L F P}^{\mathbf{a}}$} & & & \\
\hline & & $\partial \boldsymbol{X}$ & & \\
\hline Constant & $\begin{array}{l}-3.52190^{*} \\
(-3.448)\end{array}$ & & $\begin{array}{l}-1.67108^{* *} \\
(-2.330)\end{array}$ & \\
\hline $\begin{array}{l}\text { Number of } \\
\text { children }\end{array}$ & $\begin{array}{l}-0.105008 \\
(-1.593)\end{array}$ & -0.025972 & $\begin{array}{l}-0.197019^{*} \\
(-4.271)\end{array}$ & -0.049224 \\
\hline Wife's age/10 & $\begin{array}{l}0.404722 \\
(0.722)\end{array}$ & 0.1001 & $\begin{array}{l}1.11919^{*} \\
(2.819)\end{array}$ & 0.279623 \\
\hline $\begin{array}{l}\text { Wife's age } \\
\text { squared/100 }\end{array}$ & $\begin{array}{l}-0.094987 \\
(-1.314)\end{array}$ & -0.023493 & $\begin{array}{l}-0.190998^{*} \\
(-3.758)\end{array}$ & -0.04772 \\
\hline $\begin{array}{l}\text { Family after-tax } \\
\text { earnings at } H_{F}=0 \\
(10,000 \text { PTE })\end{array}$ & $\begin{array}{l}-0.013255^{*} \\
(-8.044)\end{array}$ & -0.003278 & $\begin{array}{l}-0.000762497 \\
(-0.811)\end{array}$ & -0.000191 \\
\hline $\begin{array}{l}\text { Wife's predicted } \\
\text { after-tax wage at } \\
H_{F}=20\end{array}$ & $\begin{array}{l}0.432476^{*} \\
(23.397)\end{array}$ & 0.10694 & & \\
\hline $\begin{array}{l}\text { Wife's predicted } \\
\text { after-tax wage at } \\
H_{F}=40\end{array}$ & & & $\begin{array}{l}0.0438347^{*} \\
(11.295)\end{array}$ & 0.010952 \\
\hline Log-likelihood & -719.80 & & -1460.8 & \\
\hline $\begin{array}{l}-2 * \text { Log- } \\
\text { likelihood ratio }\end{array}$ & 1754.5 & & 295.91 & \\
\hline $\begin{array}{l}\text { Critical } \chi^{2} \\
(\alpha=0.05)\end{array}$ & 11.1 & & 11.1 & \\
\hline $\begin{array}{l}\text { Cases correctly } \\
\text { predicted }(\%)\end{array}$ & 90.74 & & 75.84 & \\
\hline
\end{tabular}

Notes: ${ }^{\mathrm{a}} \mathrm{LFP}=$ labour force participation.

${ }^{\mathrm{b}} \mathrm{FTLFP}=$ full-time labour force participation.

${ }^{*}$ Significant at 1 percent level; ${ }^{* *}$ significant at 5 percent level; significant at 10 percent level.

$t$-values are shown in parentheses.

market and the 40-hour net wage to explain the probability of working full time.

The choice of these two points was based upon the analysis of married women's average weekly hours of work for the entire sample (see Table 2). The wife's after-tax pay, $W_{n}$, is therefore

(C) Fondazione Giacomo Brodolini and Blackwell Publishers Ltd 1999. 
calculated assuming that the wife works 20 hours per week (for the probability of participation in the labour market) or 40 hours per week (for the probability of full-time work). This produces an average annual wage, $W_{n}$, which is then used for the subsequent calculations.

Table 5 shows the logit estimates and reaction coefficients ${ }^{5}$ (Hartog, Theeuwes, 1985) of the labour force participation function for Portuguese married women. All of the coefficients have the expected sign.

Table 5 shows that the probability of working in the labour market is negatively influenced by the number of children and by the family income, and that it increases along with the wife's annual average after-tax income. The marginal effect of age presents the usual inverse $U$ shape: it is positive up to 23 years and negative thereafter, suggesting that Portuguese married women follow the traditional behaviour pattern of labour market activity.

For full-time participation in the labour market, all the estimates are significantly different from zero and they are of greater magnitude in absolute value when compared with the participation coefficients.

Table 6 shows participation elasticities. The denominated mean sample participation elasticities are computed as (Dagsvik et al., 1988; Ofer, Vinokur, 1985):

$$
\hat{\beta} *(1-\operatorname{prob}(Y=1)) * \bar{X},
$$

where $\hat{\beta}$ is the log-odds coefficient estimate associated with the independent variable $X ; \bar{X}$ is the mean value of $X$; and $Y$ is the dichotomous dependent variable.

Table 6. Mean sample and aggregate participation elasticities

\begin{tabular}{lcr}
\hline Elasticities & $\boldsymbol{H}_{\boldsymbol{F}}=\mathbf{2 0}$ & $\boldsymbol{H}_{\boldsymbol{F}}=\mathbf{4 0}$ \\
\hline Mean sample & & \\
Annual after-tax wage & 3.4846761 & 0.374961 \\
After-tax household income & -0.654498 & -0.043039 \\
& & \\
Aggregate & 3.4849565 & 0.278237 \\
Annual after-tax wage & $(3.05192)$ & $(0.13008)$ \\
After-tax household income & -0.66291 & -0.041804 \\
& $(0.57379)$ & $(0.02284)$ \\
\hline
\end{tabular}

Note: Standard deviations in parentheses. 
Table 7. Participation elasticities of married women in the labour market (logit estimates)

\begin{tabular}{lcc}
\hline Elasticities & Wife's wage & Income \\
\hline Mean sample & & \\
Participation elasticities & & \\
Dagsvik et al. $(1988)$ & 1.41 & -0.30 \\
Gustafsson (1992a) & & \\
$\quad$ German sample & 0.4026 & -0.3427 \\
$\quad$ Swedish sample & 0.4567 & -0.2353 \\
Riboud (1985) & 1.15 & -0.29 \\
Ofer and Vinokur (1985) & 0.49 & -0.059 \\
(without taxes) & & - \\
Dex and Walters (1992) & & - \\
$\quad$ French sample & & -0.654 \\
$\quad$ British sample & 2.70 & \\
Our results & 0.63 & \\
Full-time participation elasticities & 3.485 & -0.809 \\
Gustafsson (1992a) & & -0.340 \\
$\quad$ German sample & & -0.043 \\
$\quad$ Swedish sample & -0.059 & \\
Our Results & 0.366 &
\end{tabular}

\section{Aggregate}

Participation elasticities

Dagsvik et al. (1988)

1.14

Gustafsson (1992a)

German sample

0.383

$-0.384$

Swedish sample

$(0.174)$

$(0.269)$

0.394

$-0.258$

Our results

$(0.175)$

$(0.179)$

3.485

$-0.663$

(3.051)

(0.574)

Full-time participation elasticities

$\begin{array}{lcc}{\text { Gustafsson }(1992 \mathrm{a})^{\mathrm{a}}}^{\mathrm{a}} & -0.209 & -0.796 \\ \text { German sample } & (-1.17) & (0.439) \\ & 0.366 & -0.363 \\ \text { Swedish sample } & (0.083) & (0.170) \\ \text { Our results } & 0.278 & -0.041 \\ & (0.130) & (0.023)\end{array}$

Notes: ${ }^{a}$ These computations were performed with the estimates and average sample values presented in these papers.

${ }^{\mathrm{b}}$ Only married mothers.

Standard deviations in parentheses. 
The aggregate participation elasticities are derived from a 1 percent increase in $X$ for each individual in the sample. Following this, the average for the entire sample was calculated.

As such a wide range of results can be found in the literature, a comparison has been made with studies similar to the present one.

As can be seen in Table 7, the participation elasticities concerning annual after-tax wage are much higher than those obtained in analogous studies, with the exception of that of Dex and Walters (1992), for married mothers in France. Since this cannot be explained by the methodology, the present authors attribute it to the low acceptance of part-time work. Dex and Walters (1992) suggest lower work-related costs as a possible explanation (namely the cost of child care and the longer hours of operation for shops and banks), a situation which applies to Portugal as well.

However, income taxation is another possible underlying reason for these values. In Portugal, in 1990, the income tax system penalized the one-earner couples (couples where only one of the spouses earns more than 95 percent of the total labour income, generally the husband) (see the Appendix).

The authors should also stress the similarity of the full-time participation elasticities with respect to the wife's wage in the present sample with the Swedish sample of Gustafsson (1992a).

\section{Simulations of some fiscal reforms}

The aim is to test the sensitivity of Portuguese women's labour supply to tax changes, namely:

(a) joint income taxation with a splitting coefficient of 2.0;

(b) the same, but with the same tax credit for the couple, regardless of being a one- or two-earner couple;

(c) separate taxation for husband and wife;

(d) separate taxation with the same tax revenue as the 1990 Portuguese system; ${ }^{6}$

(e) a flat rate only (a variant of ILUR — 'Imposto Linear Único sobre o Rendimento' (Gaspar, 1989; Macedo et al., 1989a,b) which gives the same tax revenue as the 1990 Portuguese case (for further details, see the Appendix). 
Table 8. Participation rates (\%), after-tax income, taxes and wife's after-tax annual wage (1000 PTE) under different income tax systems (average values)

\begin{tabular}{|c|c|c|c|c|c|c|c|c|c|c|}
\hline Tax regime & $\begin{array}{c}\text { Particip. } \\
\text { rate at } \\
H_{F}=\mathbf{2 0}\end{array}$ & $\begin{array}{c}\text { Particip. } \\
\text { rate at } \\
H_{F}=40\end{array}$ & $\begin{array}{c}\text { Family net } \\
\text { earnings at } \\
H_{F}=0\end{array}$ & $\begin{array}{c}\text { Family net } \\
\text { earnings at } \\
H_{F}=20\end{array}$ & $\begin{array}{c}\text { Family net } \\
\text { earnings at } \\
H_{F}=40\end{array}$ & $\begin{array}{c}\text { Family } \\
\text { tax } \\
\text { liability } \\
\text { at } \\
H_{F}=0\end{array}$ & $\begin{array}{c}\text { Family } \\
\text { tax } \\
\text { liability at } \\
H_{F}=20\end{array}$ & $\begin{array}{c}\text { Family tax } \\
\text { liability at } \\
H_{F}=40\end{array}$ & $\begin{array}{c}\text { Wife's } \\
\text { after-tax } \\
\text { annual } \\
\text { wage at } \\
H_{F}=20\end{array}$ & $\begin{array}{c}\text { Wife's } \\
\text { after-tax } \\
\text { annual } \\
\text { wage at } \\
H_{F}=40\end{array}$ \\
\hline 1990 income tax & 55.168 & 48.751 & 1101.389 & 1460.842 & 1769.043 & 102.431 & 125.717 & 200.256 & 17.973 & 16.691 \\
\hline Splitting $(\mathrm{DED}=34,46)$ & 53.06 & .44 & 14.023 & 1461.428 & 1769.116 & 89.797 & 125.132 & 200.183 & 17.370 & 16.377 \\
\hline $\begin{array}{l}\text { Splitting }(\mathrm{DED}=46) \\
\text { Separate taxation with } \\
\text { tax revenue }\end{array}$ & 51.44 & 48.23 & 1122.292 & 1461.705 & 1769.137 & 81.529 & 124.858 & 200.162 & 16.970 & 16.171 \\
\hline $\begin{array}{l}\text { Different from } 1990 \\
\text { income tax }\end{array}$ & 53.92 & 49.06 & 1060.578 & 1421.450 & 1739.208 & 143.242 & 165.109 & 230.091 & 18.043 & 16.959 \\
\hline $\begin{array}{l}\text { Equal to } 1990 \text { income } \\
\text { tax }^{\mathrm{a}}\end{array}$ & 53.51 & 49.31 & $\mathrm{a}$ & 1472.305 & 1791.238 & a & 114.254 & 178.060 & 18.391 & 17.440 \\
\hline ILUR (a version) & 56.14 & 48.66 & 1101.389 & 1460.843 & 1769.043 & 102.431 & 125.717 & 200.256 & 17.973 & 16.691 \\
\hline
\end{tabular}

Notes: ' The methodology used for separate taxation with tax revenue equal to 1990 revenue tax gives rise to two different 'after-income of husband', as the household income is computed for 20 or 40 hours of wife's work. 
The impact of these systems on the wife's labour force participation is computed as:

$$
\operatorname{prob}\left(\hat{Y}_{i}=1\right)=\frac{\exp \left(\hat{P}_{i}\right)}{1+\exp \left(\hat{P}_{i}\right)},
$$

where $\hat{P}_{i}=\hat{\beta}_{0}+\hat{\beta}_{1} W_{n i}^{\Delta}+\hat{\beta}_{2} R_{i}^{\Delta}+K \hat{\beta}_{k}+A \hat{\beta}_{A} ; W_{n i}^{\Delta}$ and $R_{i}^{\Delta}$ are the wife's annual wage and the household income according to these tax systems; and $\hat{\beta}_{i}$ are the logit parameter estimates of Table 5.

Table 8 shows the results of these fiscal simulations.

As revealed in this table, the choice of tax system makes little difference on married women's labour force participation. One possible explanation is the slight effect that these systems have on the wife's after-tax annual earnings. Nevertheless, the results are in agreement with theory for participation in full-time work. That is, a shift towards separate taxation will increase the wife's labour force participation in full-time work and a shift towards splitting taxation decreases it. A shift towards a flat rate has almost no effect on this participation, which can be explained by the income distribution of this system with higher effects on the lower income couples. All of these findings are valid for participation in the labour market, with the exception of the simulations for separate taxation. In fact, with these systems, more women will refrain from participating in the labour market than under the actual tax system. Note that after the change, 2294 women maintained their working status ( 99 percent of the sample) while 28 women left the labour market, owing to a decrease in their wages that outweighed the effect of the decrease in the family income.

These results may be explained by:

- the unfavourable treatment of one-earner couples by the 1990 tax regime and the preferential treatment of two-earner couples;

- the advantages to be found in separate taxation for married women, usually with incomes lower than those of their husbands (but only in the case of full-time work in Portugal);

- the small increase in the annual after-tax earnings of the wife when separate taxation is introduced (on average, 66.54 PTE for 20 hours of work in a year) and the simultaneous decrease in family after-tax earnings at $H_{F}=0$ (on average 40,810.435 PTE), which would explain 
the small decrease in participation in the labour market with this fiscal system.

However, when these results are compared with those for Germany and Sweden (see Table 9) the results are quite different from those of the present study. The present authors believe the lower married women's wages in the Portuguese sample to be one of the possible reasons, as well as the explanations regarding the elasticity values.

Note that the findings of other studies are similar to the present one, even for the system with tax revenue held constant (Aaberge et al., 1990; Colombino, Del Boca, 1993).

Table 9. Predictions of married women labour force participation in other empirical studies

\begin{tabular}{|c|c|c|c|c|c|}
\hline \multirow[b]{2}{*}{ Empirical studies } & \multicolumn{4}{|c|}{ Fiscal systems } & \multirow[b]{2}{*}{$\begin{array}{c}\text { Increased } \\
\text { degree of } \\
\text { progression }\end{array}$} \\
\hline & $\begin{array}{c}\text { Actual tax } \\
\text { system }\end{array}$ & Flat rate & $\begin{array}{c}\text { Joint taxation }(C) \\
\text { or separate } \\
\text { taxation }(S)\end{array}$ & $\begin{array}{c}\text { Family } \\
\text { quotient } \\
\text { abolition }\end{array}$ & \\
\hline \multicolumn{6}{|l|}{ Bourguignon and } \\
\hline France & 63.1 & $67.8^{\mathrm{a}}$ & & 55.4 & \\
\hline Aaberge et al. $(1993)^{\mathrm{b}}$ & & & & & \\
\hline Italy & 40.0 & 38.0 & & & 36.0 \\
\hline Gustafsson $(1992 a, b)^{c}$ & & & & & \\
\hline $\begin{array}{l}\text { Germany } \\
\text { Sweden }\end{array}$ & $\begin{array}{l}50.3(27.8) \\
80.2(45.4)\end{array}$ & & $\begin{array}{l}60.4(\mathrm{~S})(38.5) \\
60.0(\mathrm{C})(30.6)\end{array}$ & & \\
\hline $\begin{array}{l}\text { Colombino and } \\
\text { Del Boca }(1990)^{\mathrm{b}}\end{array}$ & & & & & \\
\hline Italy & 49.2 & 46.9 & $45.4(\mathrm{C})$ & & \\
\hline Our results ${ }^{\mathrm{d}}$ & $55.2(48.8)$ & & $\begin{array}{l}53.9(\mathrm{~S})(49.1) \\
51.4(\mathrm{C})(48.2)\end{array}$ & & \\
\hline Our results ${ }^{\mathrm{e}}$ & $55.2(48.8)$ & $56.1(48.7)$ & $53.5(\mathrm{~S})(49.3)$ & & \\
\hline
\end{tabular}

Notes: ${ }^{\mathrm{a}}$ Without tax credits.

${ }^{\mathrm{b}}$ Systems with tax revenue held constant and identical to the tax revenue of the current fiscal system.

c Participation rates in full-time work in parentheses.

${ }^{\mathrm{d}}$ The $\mathrm{C}$ denotes splitting with $\mathrm{DED}=46$ and participation rates in full-time work are in parentheses.

${ }^{\mathrm{e}}$ Identical to fn. $\mathrm{d}$ but representing systems with tax revenue held constant and identical to the tax revenue of the current fiscal system. 
It is also the purpose of the present study to investigate whether or not any of these tax systems can be said to be neutral with respect to the wife's earnings (Gustafsson, 1988, 1992a; Gustafsson, Bruyn-Hundt, 1991). A fiscal system is regarded as neutral if it satisfies the following identity:

$$
\frac{W_{F} * H_{F}}{W_{M} * H_{M}+W_{F} * H_{F}}=\frac{C-R}{C},
$$

where $W_{i}$ is the hourly tax rate of individual $i(i=F$ (female), $M$ (male); $H_{i}$ is the corresponding work (expressed in hours); $C$ is the after-tax two-income earner; and $R$ is the after-tax income of the one-earner couple; that is, if the contribution of the pre-tax wife's earnings to the pre-tax family income is equal to the contribution of the after-tax wife's earnings to the after-tax family income.

It was found that:

(a) Portuguese women contribute a much larger proportion to family earnings (before and after taxes) than do German, Swedish and Dutch wives;

(b) unexpectedly, the presence of small children does not affect Portuguese wives' contributions to family earnings (as it does in the other three countries);

(c) the 1990 tax system is quite 'neutral' with respect to the wife's earnings (see definition above);

(d) the 1990 tax system penalizes the one-earner couple. So, with the unique splitting coefficient of 2.0, regardless of the deduction structure, fewer wives would participate in the labour market than they actually do (53.06 percent or 51.04 percent against 55.168 percent with the 1990 income tax system (see Table 8)). As a result, and on average, the contribution of the wife's earnings to the after-tax family income decreased slightly. It should be stressed that the same is observed in the German data (see Table 10a);

(e) with separate taxation, Portuguese women contribute more to family income after taxes (see Table 10b). (Gustafsson and Bruyn-Hundt 1991 obtained similar results in Sweden and also when they applied the Swedish fiscal system to German and Dutch couples, because the wife's contribution to family earnings is greater after taxes than before.) 
Table 10a. Women's contribution to family earnings (percent)

\begin{tabular}{lcccc}
\hline & Portugal & Germany(1) & Sweden(1) & The Netherlands $^{\mathbf{a}}$ \\
\hline $\begin{array}{l}\text { Before taxes } \\
\text { All }\end{array}$ & 0.234 & 0.150 & 0.288 & 0.119 \\
$\quad \begin{array}{l}\text { Two-earner } \\
\text { With youngest }\end{array}$ & 0.425 & 0.322 & 0.376 & 0.302 \\
child aged 0-2 & 0.262 & 0.072 & 0.246 & 0.066 \\
After taxes & & & & \\
$\begin{array}{l}\text { All } \\
\text { Two-earner }\end{array}$ & 0.231 & 0.124 & 0.166 & $0.147^{\mathrm{b}}$ \\
$\quad \begin{array}{l}\text { With youngest } \\
\text { child aged 0-2 }\end{array}$ & 0.257 & 0.310 & 0.407 & $0.369^{\mathrm{b}}$ \\
\hline
\end{tabular}

Notes: ${ }^{a}$ Source: Gustafsson and Bruyn-Hundt (1991).

${ }^{\mathrm{b}}$ Dutch system after OORT 1990 tax reform.

Table 10b. Portuguese women's contribution to family earnings (percent) as a result of tax simulations

\begin{tabular}{lccc}
\hline Portuguese couples & $\begin{array}{c}\text { Splitting } \\
(\mathbf{D E D}=\mathbf{3 4}, \mathbf{4 6})\end{array}$ & $\begin{array}{c}\text { Splitting } \\
(\mathbf{D E D}=\mathbf{4 6})\end{array}$ & $\begin{array}{c}\text { Separate } \\
\text { taxation }^{\mathbf{a}}\end{array}$ \\
\hline All & 0.227 & 0.224 & 0.239 \\
Two-earner & 0.411 & 0.407 & 0.433 \\
With youngest child aged 0-2 & 0.253 & 0.251 & 0.266 \\
\hline
\end{tabular}

Notes: ${ }^{a}$ With tax revenue different from 1990 income tax.

\section{Concluding remarks}

The OECD trends in personal income taxation are fundamentally:

- moving towards separate taxation (at least as an option);

- replacing taxable income deductions for dependant children by tax credits or family allowances; and

- decreasing high marginal tax rates.

In effect, and in terms of tax unity, it has been argued that joint taxation increases women's dependency, and thus favours 'women at home'. On the other hand, separate taxation satisfies the efficiency principle of a fiscal system (which can be translated in this case as neutrality on the part of both spouses towards the 
decision to participate in the labour market) and the neutrality with respect to marriage.

Until 1989 the taxation of income in Portugal consisted of different taxes according to their source (capital, real estate, industrial and agricultural activity and labour income) and a general surtax levied on total income. In 1989 a tax reform replaced the different income taxes with two new tax schedules: a personal income tax for individuals and a corporate income tax for legal entities. The household is assessed jointly; however, in the reform the splitting coefficient varies. It is 2.0 for two-earner couples and 1.85 for one-earner couples. So, the present authors have evaluated what the participation rate of Portuguese married women would have been if there had been only a single coefficient (equal to 2.0) or if the spouses had been taxed separately.

The empirical results confirm the economic intuition, that is:

- Tax changes that affect the take-home income have an impact on the participation of married women in the labour force. In fact, an increase in a wife's annual after-tax wage of 1 percent is estimated to raise the labour supply by 3.49 percent. This result is substantially greater than that which is usually found in the literature $(0.40$ percent (German sample - Gustafsson, 1992a) and 2.7 percent (French sample - Dex, Walters, 1992), just to cite two examples). Also, an increase in a wife's annual after-tax wage of 1 percent is estimated to increase full-time participation by 0.38 percent (mean sample elasticity) or by 0.28 percent (aggregate elasticity), while in the other studies referred to the corresponding mean sample elasticities have values from -0.059 percent to 0.366 percent. An increase of 1 percent in the after-tax household income is estimated to decrease labour force participation by 0.65 percent (mean sample elasticity) or by 0.66 percent (aggregate elasticity) and to decrease full-time labour force participation by around 0.04 percent.

- Separate taxation increases the participation in the full-time labour force from 48.75 percent to 49.06 percent or to 49.31 percent, respectively, when the tax revenue is not held constant or is held constant and equal to the 1990 tax revenue. In Gustafsson's study, separate taxation gives rise to a much higher effect on full-time participation among German wives: from 27.8 to 38.5 percent, which is associated with the magnitude of the increase in net wage that German 
wives experience and of the decrease in after-tax income of the families when they do not work.

- Separate taxation induces a decrease in the labour force participation from 55.17 to 53.92 percent (or to 53.51 percent if the tax revenue is held constant and equal to that of 1990). German wives increase their participation from 50.3 to 60.4 percent when confronted with Swedish taxes. This difference can be explained by the mean after-tax wage increase (29.2 percent for the German sample and 0.37 percent for the Portuguese one) and by the mean after-tax family income decrease when $H_{F}=0$ (27 and 3.7 percent, respectively, for German and Portuguese samples).

- The quasi-splitting tax system (existing in Portugal) induces a greater participation of women in the labour market than does the absolute splitting system (since it is unfavourable to one-earner couples), which reduces the labour force participation to values estimated between 53.06 and 51.4 percent, depending upon the specific hypotheses regarding the deductions structure.

Nevertheless, fiscal policy is only one of the factors that influence the female labour supply. Among others, subsidized child care and parental leave can be mentioned. Therefore, future research is needed in order to consider these factors and to contemplate the joint decision which the household makes regarding working and having children.

\section{Appendix}

\section{Personal income taxes in Portugal in 1990}

The main features of the Portuguese personal income tax in 1990 used in the computation of after-tax family income were:

(i) the tax unit is the family, so the earnings of the dependant children are assessable with those of the parents. However, the sample constructed by Sentieiro (1992), presents no available information in this regard. Consequently, the household income is set equal to the earnings of the couple;

(ii) the tax base in this sample consists of the annual family income; 
(iii) the annual taxable family income is calculated as the annual gross family income after the following deductions:

- sixty-five percent of the gross earnings up to 300,000 PTE or the total social security payments, if greater than 300,000 PTE (Deduções Especificas, personal deductions);

- a non-standard tax relief (for instance, for dependants' education, certain insurance premiums, interest on housing loans, etc.) of 105,000 PTE for a married couple if greater expenses are not documented (which is the case in this sample);

(iv) the tax schedule for 1990 is shown in Table A1.

(v) the income tax liability is computed for each bracket as follows:

$$
\begin{aligned}
\operatorname{tax}=\text { taxable income } & \times \text { marginal tax rate } \\
& - \text { amount to deduct }- \text { tax credit; }
\end{aligned}
$$

(vi) for married couples the income tax liability is calculated as:

$$
\left(\frac{\text { Pinc }_{m}-D R_{m}+P i n c_{f}-D R_{f}-105,000}{2} \times t-P A\right) \times 2-T C,
$$

for two-earner couples, where Pinc $_{m}$ is the gross annual income of the husband; inc $_{f}$ is the gross annual income of the wife; $D R_{m}$ is personal deductions (Deducões Especificas) for the husband; $D R_{f}$ is personal deductions (Deduçoes Especificas) for the wife; $t$ is the marginal tax rate; $P A$ is the amount to deduct, corresponding to the bracket of income; and $T C$ are the tax credits of 46,000 PTE for the married couple and of 12,000 PTE for each dependant.

\section{Table A1}

\begin{tabular}{lcc}
$\begin{array}{l}\text { Taxable annual income } \\
\text { (1000 PTE) }\end{array}$ & Marginal tax rate (\%) & $\begin{array}{c}\text { Amount to deduct } \\
(\mathbf{1 0 0 0} \text { PTE) }\end{array}$ \\
\hline Up to 540 & 16 & 0.0 \\
540 to 1020 & 20 & 21.6 \\
1020 to 1500 & 27.5 & 98.1 \\
1500 to 3600 & 35 & 210.6 \\
Over 3600 & 40 & 390.6 \\
\hline
\end{tabular}


For one-earner couples:

$$
\left(\frac{\text { Pinc }_{m}-D R_{m}-105,000}{1.85} \times t-P A\right) \times 2-T C,
$$

where the tax credit is now 34,000 PTE for the married couple and 12,000 PTE for each dependant.

\section{Fiscal systems implemented in this study}

2.1 Joint taxation with splitting method. For this case it is considered that the splitting coefficient is 2.0 for all the married couples. But the tax credits are those indicated for the one- and two-earner couples in the Portuguese income tax (the authors maintain the tax schedule and the deductions for taxable income calculation).

2.2 Joint taxation with splitting method $(D E D=46)$. For this system, the splitting coefficient is considered to be 2.0 (whether a one- or two-earner couple) and that the tax credits are those of the two-earner couple. All of the remaining features described in Section 1 of this Appendix are held constant.

2.3 Separate taxation. In this system it is assumed that the tax unit is the individual and that the deductions and tax schedule are the same as Portugal's. However, the non-standard tax relief is now the same as for unmarried individuals: 52,500 PTE and the tax credits are 23,000 PTE for each taxpayer and 6000 PTE for each dependant child.

The after-tax household income is now the sum of the after-tax income of each spouse.

2.4 Separate taxation calculated as 1990 tax revenue. This is the same as in Section 2.3 above except the marginal tax rates and the amounts to deduct are adjusted (that is, the average tax rate) so as to obtain a tax revenue identical to that of 1990. The coefficient of adjustment for $H_{F}=20$ is computed as follows:

$$
\frac{(1-L F P) * T A X\left(H_{F}=0\right)+L F P * T A X\left(H_{F}=20\right)}{(1-L F P) * T A X S\left(H_{F}=0\right)+L F P * T A X S\left(H_{F}=20\right)},
$$


Table A2. Tax regressions

Tax revenue when:

\begin{tabular}{lccc}
\cline { 2 - 4 } Regressors & $\boldsymbol{H}_{\boldsymbol{F}}=\mathbf{0}$ & $\boldsymbol{H}_{\boldsymbol{F}}=\mathbf{2 0}$ & $\boldsymbol{H}_{\boldsymbol{F}}=\mathbf{4 0}$ \\
\hline Constant & $-132.9492^{*}$ & $-187.8526^{*}$ & $-280.2533^{*}$ \\
Gross household income & $(-133.322)$ & $(-103.791)$ & $(-115.270)$ \\
& $0.1955279^{*}$ & $0.197641^{*}$ & $0.2440003^{*}$ \\
Adjusted $R^{2}$ & $(267.195)$ & $(198.832)$ & $(234.132)$ \\
$F$ & 0.9685 & 0.9445 & 0.9594 \\
\hline
\end{tabular}

Notes: In these regressions, the constant denotes the tax credit and the income coefficient, the marginal tax rate.

For the other fiscal reforms with tax revenue equal to 1990, the gross earnings of the wife must be re-computed. This has been done with the use of a FORTRAN program, which is available on request from the authors.

* Significant at 1 percent level

$t$-ratios are shown in parentheses.

where all of the variables are evaluated at the mean and $T A X($. denotes the 1990 tax revenue when the wife works; $H_{F}$ is hours in the labour market; and $T A X S($.$) is the tax revenue when separate$ taxation is implemented. The same procedure is adopted for fulltime participation in the market.

2.5 Flat rate (ILUR). This is a variant of a proposal of Macedo et al. (1989a,b) (Gaspar, 1989) known as ILUR (Imposto Linear Unico sobre o Rndimento), by which there will be only a flat rate. In this paper the present authors consider a variant of that system, but with tax revenue equal to that of the Portuguese income taxation of 1990. For that, a tax function is estimated by OLS, where the dependent variable is the tax revenue when the wife works a specified number of hours $(0,20$ or 40$)$ and the exogenous variable is the gross household income for the same wife's work hours. The tax regressions are shown in Table A2.

\section{Notes}

${ }^{1}$ Eurostat (1996), 'Enquête sur les forces de travail — Résultats 1996'.

${ }^{2}$ Data are available upon request from the authors. 
${ }^{3}$ Even though Euros did not exist in 1990 the conversion is included in order to aid the reader: 1 Euro $=200$ PTE.

${ }^{4}$ Twelve months of regular salary plus a one month salary bonus in July and another in December.

${ }^{5}$ The reaction coefficients give the marginal effect of any independent variable on the probability of having $\mathrm{LFP}=1$ or $\mathrm{LFP}=0$ (or FTLFP $=1$ or FTLFP $=0$ ) for any observation. For the probability of labour force participation, they are calculated as $\beta *$ prob $(\mathrm{LFP}=1) *(1-\operatorname{prob}(\mathrm{LFP}=1))$, evaluated at the mean of prob $(\mathrm{LFP}=1)$ (Greene, 1990; Maddala, 1983, 1989; Riboud, 1985).

${ }^{6}$ No attempt is made to align joint income taxation with the same tax revenue as the 1990 Portuguese case, since tax revenue under systems (a) and (b) are very similar to 1990 tax revenue. For further details see the Appendix.

\section{References}

Aaberge R., Colombino U. and Ström S. (1993) 'Labor Supply in Italy', Discussion Paper 92, Research Department, Central Bureau of Statistics, Norway.

Agell S. A. and Apel M. (1991) 'Female Labor Supply and Taxes in Sweden - a Comparison of Estimation Methods', Paper presented at the EALE Third Annual Conference, El Escorial, Spain.

Bourguignon F. and Magnac T. (1990) 'Labor Supply and Taxation in France', Journal of Human Resources 25: 3, 358-389.

Brownstone D., Englund P. and Persson M. (1988) 'A Microsimulation Model of the Swedish Housing Demand', Journal of Urban Economics 23: 179-198.

Colombino U. and Del Boca D. (1990) 'The Effect of Taxes on Labor Supply in Italy', Journal of Human Resources 25: 3, 390-414.

Dagsvik J. K., Laisney F., Ström S. and Östervold J., (1988) 'Female labour supply and the tax benefit system in France', Annales d'Économie et de Statistique 11: 5-40.

Dex S. and Walters P. (1992) 'Franco-British Comparisons of Women's Labour Supply and the Effects of Social Policies', Oxford Economic Papers 44: $89-112$.

Eurostat (1996) Enquête sur les forces de travail - Résultats 1996. Office des Publications Officielles des Communautés Européennes.

Fernandes F. P. and Santos J. C. (1990) Código do imposto sobre o rendimento das pessoas singulares - anotado e comentado, 2nd edn, Lisboa: Rei dos Livros.

Gaspar V. (1989) ‘A reforma fiscal em Portugal: condicionantes e oportunidades', Nova Economia 4: 44-47.

Greene W. H. (1990) Econometric Analysis, New York: MacMillan.

Gustafsson S. (1988) 'Income Taxes and Women's Economic Dependency: a Comparison of West Germany and Sweden', CEPR Discussion Paper No. 281.

Gustafsson S. (1992a) 'Separate Taxation and Married Women's Labor Supply - a Comparison of West Germany and Sweden', Journal of Population Economics 5: 61-85. 
Gustafsson S. (1992b) 'Public Policies and Women's Labor Force Participation: a Comparison between Sweden, The Netherlands and Germany', Paper prepared for the Conference on Women's Human Capital and Development, Bellagio, Italy.

Gustafsson S. and Bruyn-Hundt M. (1991) 'Incentives for Women to Work: a Comparison between The Netherlands, Sweden and West Germany', Journal of Economic Studies 18: 5/6, 30-65.

Hartog J. and Theeuwes J. (1985) 'The Emergence of the Working Wife in Holland', Journal of Labor Economics 3: 1, S235-S255.

Heckman J. (1980) 'Sample Selection Bias as a Specific Error', Econometrica 47: $153-162$.

Macedo J. B., Gaspar V. and Sarmento L. M. (1989a) 'Imposto linear único sobre o rendimento: perspectivas e oportunidades para a reforma fiscal em Portugal', Working Paper No. 108, Faculdade de Economia, Universidade Nova de Lisboa.

Macedo J. B., Gaspar V. and Sarmento L. M. (1989b) 'Uma reforma fiscal para 1992: imposto linear único sobre o rendimento' in Sousa A. et al. (eds.) Nova Economia Em Portugal (Estudos em homenagem a António Manuel Pinto Barbosa), Lisbon: Faculdade de Economia, Universidade Nova de Lisboa.

Maddala G. S. (1983) Limited-dependent and Qualitative Variables in Econometrics, Cambridge: Cambridge University Press.

Maddala G. S. (1989) Introduction to Econometrics, New York: Maxwell MacMillan International edition.

Meulders D., Plasman R. and Stricht V. V. (1991) 'Position of Women in the Labour Market-developments between 1983 and 1989-90', Dulbea, Department of Applied Economics, Free University of Brussels.

Ofer G. and Vinokur A. (1985) 'Work and Family Roles of Soviet Women: Historical Trends and Cross-Section Analysis', Journal of Labor Economics 3: 1, S328-S354.

Riboud M. (1985) 'An Analysis of Women's Labour Force Participation in France: Cross-section Estimates and Time-series Evidence', Journal of Labour Economics 3: 1, S177-S200. 